Article

\title{
Sustainable Development in Geography Education for Middle School in China
}

\author{
Fengtao Guo ${ }^{1}$, Joseph Lane ${ }^{2}$, Yushan Duan ${ }^{1, *}$, Joseph P. Stoltman ${ }^{3}$, Olga Khlebosolova ${ }^{4}$, \\ Hao Lei ${ }^{5}$ and Weiguo Zhou ${ }^{1}$ \\ 1 School of Geographic Sciences, East China Normal University, Shanghai 200241, China; \\ 52110801002@ecnu.cn or fengtao.guo@foxmail.com (F.G.); zhouweiguo21@126.com (W.Z.) \\ 2 Division of Social Science and History, Delta State University, Cleveland, MS 38733, USA; \\ jlane@deltastate.edu \\ 3 Department of Geography, Western Michigan University, Kalamazoo, MI 49008, USA; \\ joseph.stoltman@wmich.edu \\ 4 The Department of Ecology and Geography, The Sergo Ordzhonikidze Russian State University for \\ Geological Prospecting, Moscow 117997, Russia; o.hlebosolova@mail.ru \\ 5 Institute of Curriculum and Instruction, East China Normal University, Shanghai 200062, China; \\ hlei@kcx.ecnu.edu.cn \\ * Correspondence: ysduan@geo.ecnu.edu.cn; Tel.: +86-137-017-15221
}

Received: 25 September 2018; Accepted: 23 October 2018; Published: 26 October 2018

\begin{abstract}
Education for Sustainable Development (ESD) had become a priority in many school systems. Geography has a tradition of investigating human-environment interactions and geography education is vital to make sense of sustainable development (SD). In this paper, the authors aimed to contribute to the implementation of ESD and SD in middle school geography, in The People's Republic of China. This research employed a series of methods to analyze the content in (SD) in middle school geography standards and textbooks. The research surveyed geography teachers $(n=237)$ and assessed geography students $(n=246)$. Results exemplified both positive and negative conclusions from the data. Primarily, the findings suggested that geography education was important to ESD implementation, although the requirements for SD are low in the selected middle schools. The SD content was reflected clearly in the content standards and textbooks, but it was not evenly distributed in geography education. Many geography teachers in China have ample geography and interdisciplinary knowledge and they can use textbooks and other teaching methods to teach SD. The students' performance, in a sample of four key schools, was considered "OK", however there was still room for improvement. Most students were familiar with people, resources, environmental problems, and climate change, however, most were unable to grasp the factual knowledge about SD, such as international events and documents, latest predicted data, and research on global warming, as well as the indicators used in the specific SD assessment. Suggestions include providing students with more practical activities and a chance to do hands-on experiments, as well as building student organizations and clubs, improve Teachers' knowledge, and understanding through teacher training program and build a platform for communicating ideas of SD through modern communication technology. Ideas of SD should be integrated into students' daily life.
\end{abstract}

Keywords: sustainable development; geography education; implementation; China

\section{Introduction}

China, as the world's most populous state, has achieved steady and rapid economic development. From an educational standpoint, the nation is currently faced with a series of major challenges that have 
potential to slow this rapid economic growth. Geography education in China has been a mandatory subject in school as it inspires student response to challenges, and it introduces the students to worldwide perspectives. Since 1904, Geography has been a part of the curriculum in both elementary and middle school education. The basic education curriculum has experienced eight waves of change since the founding of the new China in 1949 [1]. At present, the specific content focus on geography begins in middle school when students participate in their first specialized Geography course. As an obligatory course in middle school, geography can be studied as a stand-alone subject or as part of an integrated approach for Grade 7 and Grade 8. When the study of geography is subject specific, such as a specific geographical region, there are usually two classes every week for approximately ninety minutes. Geography education is high-stakes, especially in high school; where college entrance examinations are required. All Chinese students are required to study geography to successfully complete the required state exams. In the National College Entrance Examination (NCEE), commonly known as Gaokao, students must choose between two concentrations: Social science or natural science. The students who choose the social science concentration receive further testing in history, politics, and geography. The students who choose the natural sciences are tested in physics, chemistry, and biology. In all, the above reasons broadly illustrate why geography has the potential to support Education for Sustainable Development (ESD).

The author's primary goal in this research was to analyze and assess the situation and implementation for ESD in geography education for middle schools in China. Assessing the progress and implementation of Sustainable Development (SD) and Educational Sustainable Development (ESD) was one of the objectives in the 2012 United Nation Conference on Sustainable Development [2].

Guiding Research Questions

This research was guided by three questions, they were:

How do geography standards and textbooks reflect the SD content in China?

What challenges face the practice of SD in Chinese geography education?

What are some ways to improve SD in Chinese geography education?

\section{Literature Review}

Broadly speaking, there are several international environmental organizations that help shape global environmental policies and improve environmental security and sustainability worldwide [3]. Much of the international ideas of ESD and SD address serious environmental problems, as well as provide suggestions as to what should/could be done about them [3]. The concept of SD was first formulated at the 1972 United National Conference on the Human Environment in Stockholm, Sweden. According to Brundtland Report [4], modern concepts of SD, met the needs of the present without compromising the ability of future generations to meet their own needs. While the term SD is used widely by educators, economists, and politicians, it is often interpreted differently by independent interest groups [5].

In 1994, The Chinese government issued a national-level SD plan called. "China's Agenda 21.: This plan emphasized geography, as an important discipline supporting SD [6]. In Chapter 6, this report illustrated that "content regarding resources, ecology, environment and sustainable development should be integrated into "nature" of elementary school, "geography" in secondary schools and in other courses" [6].

ESD enables students to develop the knowledge, values and skills needed to influence and understand their decisions regarding the way we do things individually and collectively [7]. ESD also enables both local and global entities, that will improve quality of life without damaging the planet for the future [7]. ESD can impact student learning outcomes in terms of their sustainability consciousness [8]. The purpose of ESD is to support the younger generation in acquiring the knowledge, skills, attitudes, and values necessary to shape a more sustainable future $[9,10]$. 
ESD seems to have been insufficiently implemented in secondary science education in many countries. This is generally due to lack of suitable experiments, coupled with missing teaching and learning materials along with insufficient teacher professional development [11]. Geography as a discipline has an important role in teaching SD [12,13]. While notions of people and the environment have long been associated with school geography [14,15], an explicit remittance for geography educators to teach about SD is more recent $[16,17]$.

School geography provides a suitable context for exploring pupil's experiences of ESD. There has been some research into the relationship between geography and ESD. Through the holistic analyzation of the geography curriculum, many researchers argue that geography, with specific and decisive content regarding SD in schooling, is a core subject in middle schools. Implementing SD into geography helps provide students with a better understanding of the importance of the topic. Some teachers only instruct on the part of textbook that explains the ideas of SD [18]. Some teachers suggest employing three teaching strategies, including; inquiry-based learning, experience-based learning, and practice-based learning [19]. Wang has been analyzing the literature regarding geography teaching and SD since 2001. Wang investigated content about SD in the geography textbooks, the evaluation of SD, and the environmental literacy of geography teachers. He concluded that there is still much need for improvement [20]. There are no systematic or comprehensive analyzations regarding SD content in the geography textbooks.

There are increasing expectations put on young people to acquire the ability to engage with the concepts of SD. This engagement is highly relevant to individual life experience [21]. However, there still appears to be relative scarcity in published research regarding the implementation of SD in middle school, as well as the aim of exploring school students' understandings of sustainability [22]. Corney and Reid [23], Chalkley, Blumhof, and Ragnarsdóttir [24] highlighted the widespread recognition of the major contributions of geography teaching in ESD, specifically within England. Perhaps more importantly, these authors highlighted pedagogy that is often characterized by geographical inquiry $[25,26]$. In turn, they concluded that based on constructivist approaches to learning students acted as dynamic co-constructors rather than passive recipients of knowledge within and outside the classroom [23]. There are several pedagogic approaches in ESD. A list of strategies which include; developing teachers' competencies models [27], integrating existing ESD theoretical frameworks into teacher education curriculum [28], role playing and simulation activities, group discussions [29], and stimulus activities (such as watching a video or looking at poetry to initiate reflection or discussion: e.g., in Reference [30], debates, use of case studies, critical reading and writing [31], problem-based learning, and fieldwork) [5].

\section{Materials and Methods}

This research applied a range of assessment techniques to illustrate a detailed perspective of SD in geography education: The method design consisted of three phases.

Phase 1-analysis of the geography standards and textbooks

Standards and textbooks are the primary source for the learning of subject knowledge and understanding which pupils need to develop during their schooling [32]. The authors primarily analyzed the Geography Curriculum Standards for Compulsory Education, published by the Chinese Ministry of Education in 2011. Geography Textbooks for, Grade 7 and Grade 8, which were published by People's Education Press in 2012, were also analyzed.

The standards and textbooks were first presented to the authors as raw narrative data. The analysis began by reducing the narratives into more easily categorized themes. This was accomplished through coding and recoding processes. Once the simplistic codes were identified for each category, the authors then searched for relationships between similar codes. Finally, the related codes were combined into their respective categories. The initial coding was done by the first author who then redistributed the raw narrative data, along with his suggestions, to the contributing authors [33]. 
To gain a holistic view of the distribution of ideas regarding SD in geography education in middle school, the authors employed content analysis. Ten categories of SD were designed to analyze the standards and textbooks. The ten categories of SD were designed according to the "Lucerne Declaration on geography education for sustainable development" [34]. The ten categorizes were (1) place in standard and textbooks; (2) fundamental ideals; (3) international documents; (4) instruments of interstate regulation; (5) indicators; (6) fundamental issues; (7) theoretical knowledge; (8) empirical knowledge; (9) aspects of education; and (10) methods and approaches on geographical education for sustainable development (See Appendix A).

In each category, the authors listed aspects of SD and ESD that were reflected within the instruction of middle school geography students. For example, fundamental issues (Category \#6) had twenty aspects (Figure 1).

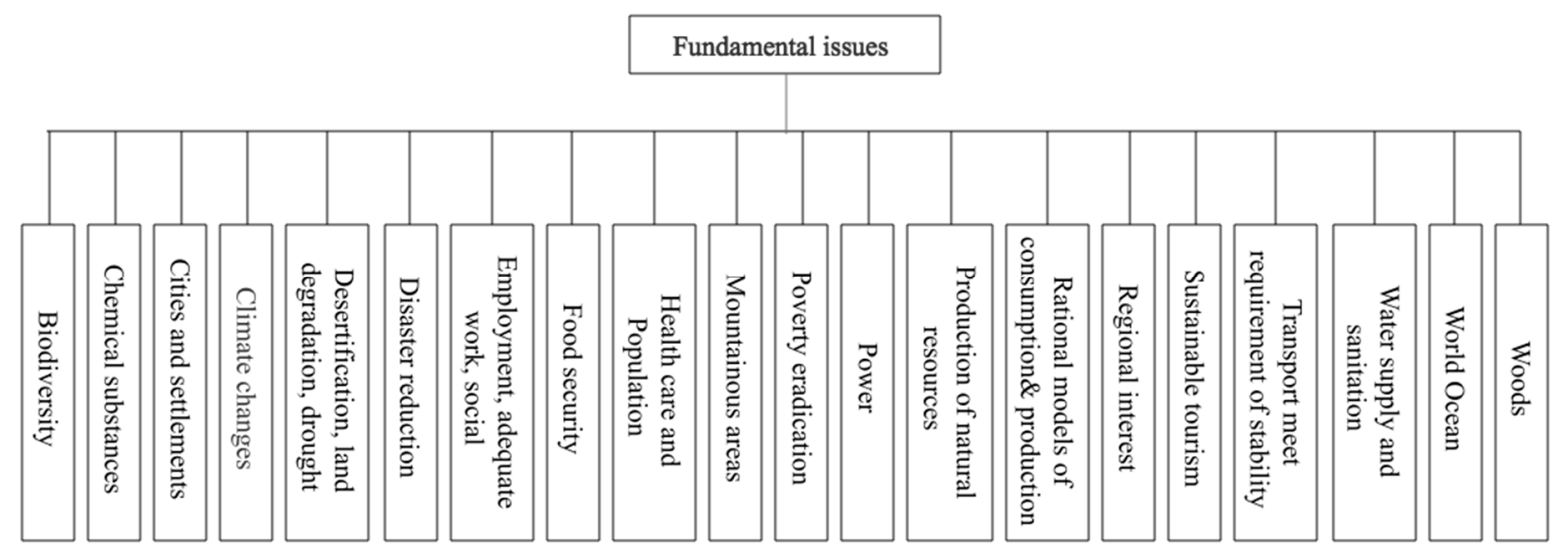

Figure 1. The framework of fundamental issues.

Phase2-Survey of geography teachers using questionnaire and interview data

The questionnaire employed a standardized format designed to gather information about the opinions and behaviors of individuals [35]. For example, participants were asked to state their extent of agreement using a 4-point Liker-type scale, ranging from 1 (strongly disagree) to 4 (strongly agree). The questionnaire gathered information regarding teachers' backgrounds, teachers understanding of standards and textbooks, teaching methods, and teaching suggestions.

A pilot study employing a sample of 10 teachers, was used to ensure clarity in the readability of the survey questions and employ face validity to the research instrument [36]. Comments and feedback from the participants led to modifications of the wording within the questionnaire. The modification and rewording decreased the questions from 22 to 19 items. This was done to simplify the process for the teachers (Appendix B).

The research employed an online survey of geography teachers in 29 provinces through an online network platform called a QQ Group. QQ is a social networking software that is primarily used in China. The software can be compared to "Skype" in its practical function. QQ Group, one of its services, was designed to connect users with similar research interests. It provided a platform for professionals with similar interests to collaborate ideas. Data were collected in the QQ Group by means of a questionnaire.

When an individual teacher completed the questionnaire, the QQ Group provided the necessary communication platform needed to keep the data organized and the communication circulating. The authors collected data from 237 geography teachers $(n=237)$. Most teachers had more than six years teaching experience and had earned a bachelor's degree in geography or a similar discipline. Finally, the authors primarily employed descriptive analysis for the data statistics.

Phase3-testing the sustainable development capability of students in four middle schools 
The research tested students through a 25 item questionnaire, which included 24-short answer questions and 1 multiple-choice question. Each item was given a score from 1 to 6 . The total score, of all 25 items, was 100. The items consisted of five sections (Appendix C), which were originally developed by Olga Khlebosolova [37]. The test was mailed to the geography teachers. The teachers then got approval from the School and Parent Councils. The teachers then surveyed the students in the classroom, and finally returned the questionnaires.

The average age of the participants was 16, and students ranged in age from 14 to 19-years-old. The student population sample contained slightly more girls (62.6\%) than boys (37.4\%). Therefore, incomplete surveys were not removed from the data set. This method was useful for the reflection of the holistic levels of students' understanding of SD. Based on the test results, the authors divided the scores into four categorical levels, 0-17, 18-50, 51-80, and 81-100. For example, the students who scored more than 18 earned a passing score, those who scored higher than 81 were considered very good. The authors then employed a difficulty and discrimination analysis using Excel 2013 and SPSS 23 . The difficulty analysis reflected the degree of difficulty within each item on the test. The following formula was employed in the research:

$$
P=\frac{\bar{X}}{W} \times 100 \%
$$

In this formula, $\mathrm{P}$ represented the difficulty index. $\mathrm{X}$ represented the average score of each individual item on the questionnaire and $\mathrm{W}$ represented the full marks. The higher the $\mathrm{P}$ value, the less difficult the item was.

The discrimination index served as a test for validity. For each test item, the method of calculation was the Pearson Correlation, and SPSS 23 was used for the calculation of the analysis.

The discrimination index can be explained as follows; if the value of discrimination index is more than 0.4 , this indicated the discernment of that item was very good. If the value was between $0.3-0.39$, this illustrated that the discernment of the item was good. If the value was between $0.2-0.29$, this indicated that the discernment of item was OK, but the item needed modification. If the value was less than 0.19 , this indicated that the discernment of the item was bad and should be deleted.

All procedures performed in this research involved human participants. This research was in accordance with the ethical standards of East China Normal University. In addition, this research complies with the 1964 Helsinki declaration and its later amendments and comparable ethical standards.

\section{Findings}

\subsection{Sustainable Development of Geography Standards and Textbooks}

In this section, the authors present the findings in terms of categories (Appendix A) and content analysis. SD was clearly reflected in the content of the geography standards for middle schools. In China, geography standards are a source for guidance in the compiled textbooks of geography teaching, learning, and evaluation. In the 33-page geography standards for middle schools, there are nearly 60 sentences of content standards related to SD.

The content regarding SD were not evenly distributed within the geography standards. As you can see from Figure 2, different lines indicated the sum of the standards regarding SD within each topic. The content standards for China followed a grade-to-grade progression with 100 specific geographic content standards being addressed in middle schools [1,38]." The content analysis findings related to SD for the geography standards were summarized in Figure 2, "understand the region" and "natural environment and resources" This included more than the five content standards related to SD. For example, "regional development" and "environment and development" had four standards regarding SD. However, there were no content standards related to SD in "land and ocean", "areal differentiation", or "location and distribution". 


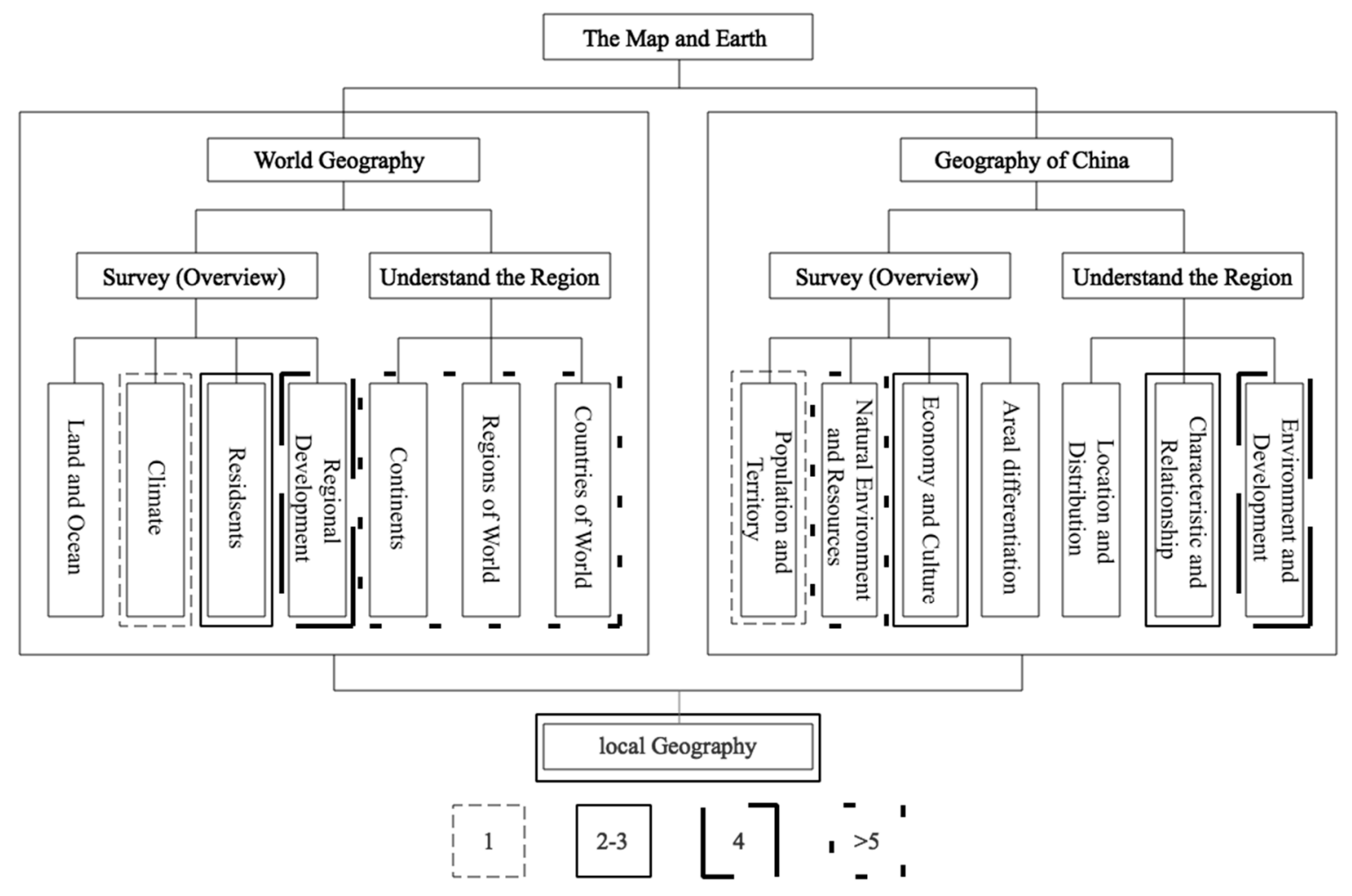

Figure 2. The number of standards regarding SD in each topic of middle school.

In China, the textbooks are nearly identical to the standards. This is especially true for the first semester textbooks in Grade 7 and Grade 8. The other two textbooks are World Geography and Geography of China. These textbooks investigated several regions in China to meet the requirement of "Understand the Region" in geography standards.

Content standards were closely related to SD in four geography textbooks, however there was more SD content in Grade 8, then on Grade 7. From the topic of global scale, ESD content in geography was mainly elaborated in Sub-Saharan Africa, Brazil, India, Southeast Asia, and Australia. From the sub-region perspective, ESD in geography was focused on ecological and environmental regions; such as the Leoss plateau, in Sanjiangyuan.

$\mathrm{SD}$ is one of the objectives within geography education. In the standards, the Ministry of Education of the People's Republic of China, reported that "knowing the environment and developmental issues, enhanced patriotic emotion, developed preliminarily global consciousness and ideas of SD and was part of the general education objectives [38]." SD in Geography mainly focused on issues of environment and development, highlighted the process of geographical thinking and solutions to geographic questions, and cultivated the scientific development view of the man-earth relationship. There were many key ideas of SD mentioned in the textbooks and the standards. These included cherish and save physical resources, the concept of adopting measures suiting local conditions, harmonious world and harmony between man and earth, Ecological civilization, and scientific development.

In categories 3, 4, 5, 7, and 10 the content regarding theoretical knowledge, international documents, instruments of interstate regulation, indicators, and methods and approach of SD were all inadequate. For example, the content did not address theoretical knowledge, doctrines or theories, regularities, or hypotheses within these geography textbooks. Only brief mention of a few related SD concepts were found; these included such topics as tree planting and grass growing, returning arable land into forest, social and economic development, returning farmland to lake, ecological benefits, environmental benefits, and economic benefits. Furthermore, there were many international documents about SD that were not found in the geography textbooks. These textbooks only mentioned a Convention Concerning the Protection of the World Cultural and Natural Heritage (1972); a convention 
on the global ban of whaling (1986), the Antarctic Treaty (1959), and the Arctic Environmental Protection Strategy (1991).

While cartographical methods, statistical methods, comparative, and geographic methods were used to present SD, geographical modeling and forecasting, geospatial technologies, environmental approaches, and interdisciplinary approaches were not mentioned in the textbooks.

For categories 6, 8, and 9, the content about SD in geography education is still in need of revision, although the fundamental, empirical knowledge, and aspects of education, have illustrated many positive characteristics. The textbooks used facts, figures, and examples of several countries to illustrate empirical knowledge. Many aspects of education were important for geography as well as SD, such as risks and prevention. Furthermore, nearly all the fundamental issues, found in standard 6 (Figure 1), were integrated into geography textbooks. This is true, except for poverty eradication, food security, employment, decent work, social protection and chemical substance education.

In a deeper analysis, the authors identified additional thought-provoking findings as well. The following thought-provoking findings are described below:

First, the requirements of SD are low for middle school students in China. In most cases, the content that is associated with SD was brief. For example, the standards stated the importance of illustrating the experience and lessons of a country's natural resource development and environmental protection [38].

Second, through analysis of textbook pages which had SD content, the authors found 26 themes regarding SD. Figure 3 illustrated the SD content regarding agriculture, water resources, inequality, and cooperation. For example, the content regarding agriculture included agriculture development according to the local conditions, as well as employing science and technology. The content that related to inequality and cooperation included developmental differences as well as inequality between developing and developed countries.

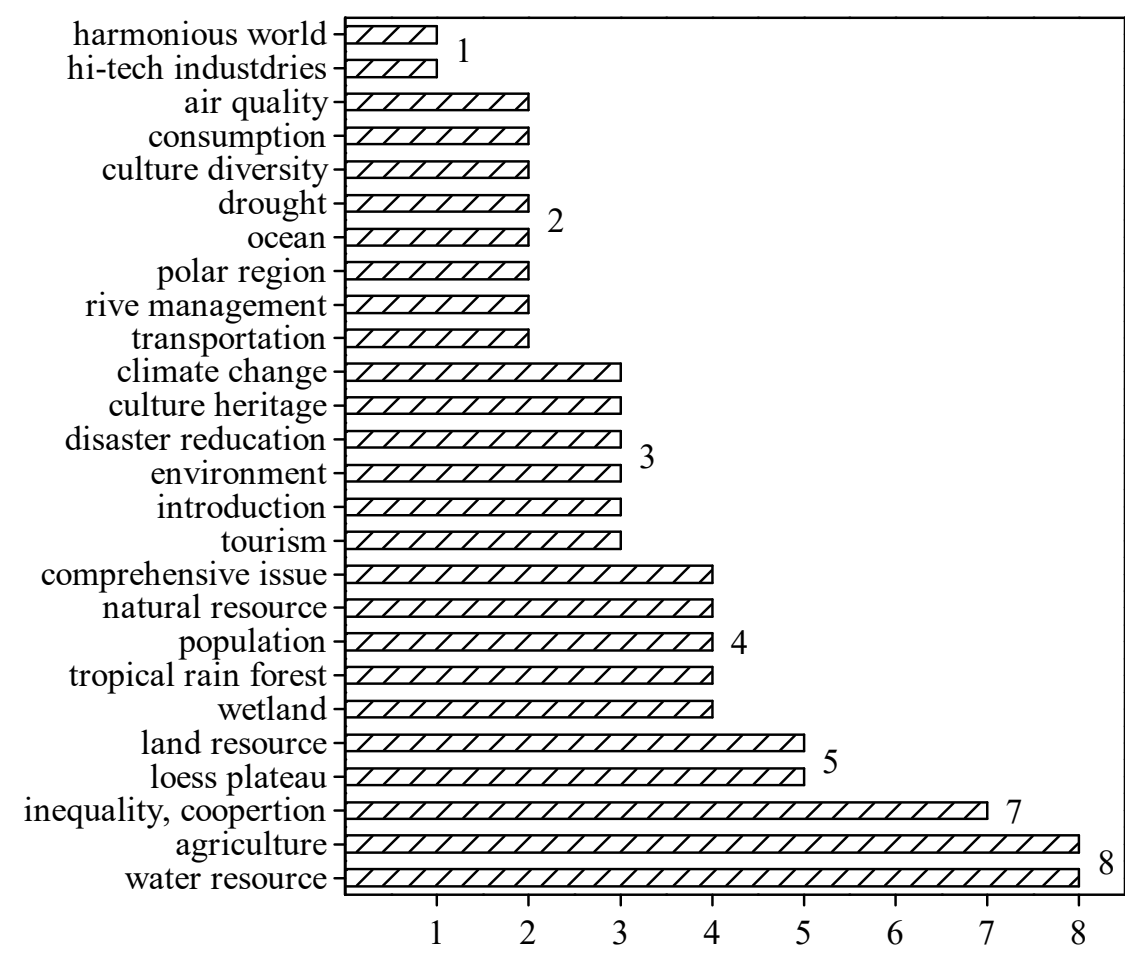

Figure 3. Themes and pages which have SD contents in geography textbook.

In addition, some topics, such as Management and Protection of the Yangtze River, the Yellow River, natural resources, land resources, exploitation and protection of tropical rain forests, wetlands, 
population problems (India, China), earthquake warnings and prevention (Japan and China), drought, and gas (west-east gas pipeline) were given more attention within the textbooks.

Third, most textbook content related to SD was presented as an activity or reading material. For example, regarding the mining industry in Australia, the text implied that "Australians pay more attention to environmental protection during mining, and this shift towards ESD has formed a culture of the human-environment integrated relationship" in the reading material of textbook [39]. The activity content was not simply narrated with factual information. The textbooks provided numerous ways to teach SD, such as role playing, seminars, giving speeches, etc. For example, when examining Southeast Asia, the textbook provided the activity "organize the seminar based on the topic of protecting the orangutans and eating less instant noodles" [40].

The textbooks presented the activity regarding land resources as follows. This interesting activity (Tables 1 and 2) was used to cultivate students' awareness of SD by role playing.

Table 1. The prescription for Arable land.

\begin{tabular}{l}
\hline \multicolumn{1}{c}{ "Arable Land" Clinic } \\
\hline "diagnose": \\
1. excessive deforestation \\
2. Deforest and reclamation \\
3. Serious soil erosion \\
\hline
\end{tabular}

Table 2. The prescription for Construction land.

\begin{tabular}{l}
\hline \multicolumn{1}{c}{ “Construction Land" Clinic } \\
\hline "diagnose": \\
1. pell-mell development \\
2. extensive management \\
\hline
\end{tabular}

Understand our national land policy [41].

Basic national policies offered suggestions to rational utilization and protection of land combined with national conditions clarifies understanding within SD.

1. "land specialist clinic"

If you are a "land doctor", please make a "effective prescription" for land.

2. "The planning of land expert"

If you are a "land planner", you are to implement measures of reasonable utilization and protection against land that is difficult to use, such as desserts and high mountains.

Dessert and Gobi, Snow Mountain

Cold dessert Rocky Mountains

3. "Land day propaganda"

25 June is the day of "land conduct propaganda" in China. If you are a volunteer, please find the topic of this year and advertise to the public around you.

\subsection{Teachers' Viewpoint and Student's Sustainable Development Capability}

Teacher opinions were one of the aspects of SD in the standards, programs, textbooks, and methodical recommendations. First, the findings suggested that most geography teachers surveyed had ample knowledge and ability to teach SD. Eighty-seven percent of the geography 
teachers who participated in the research, believed that the geography standards explicitly stated the SD content. Only about one and a half percent of the teachers did not explicitly identify the content regarding SD. This was true with both the standards and in textbooks. Ninety-eight percent of geography teachers who participated in the research believed that students developed ideas of SD when they were involved in preparing SD lessons. Ninety-four percent of teachers, who participated in this research, could apply interdisciplinary knowledge required to implement SD standards into their curriculum.

Second, the geography teachers used the activities and reading material in the textbooks, and extended the content based on the standards. Teachers' experience was found to be very important. An experienced teacher could help students better articulate the concept of SD. While eighteen percent of geography teachers never used the activities and reading material, due to limited class time, half of the participants often completed the activities based in the textbooks. As illustrated in Figure 4, more than half of the geography teachers, who participated in the research, choose content in the textbook that involved talking with students.

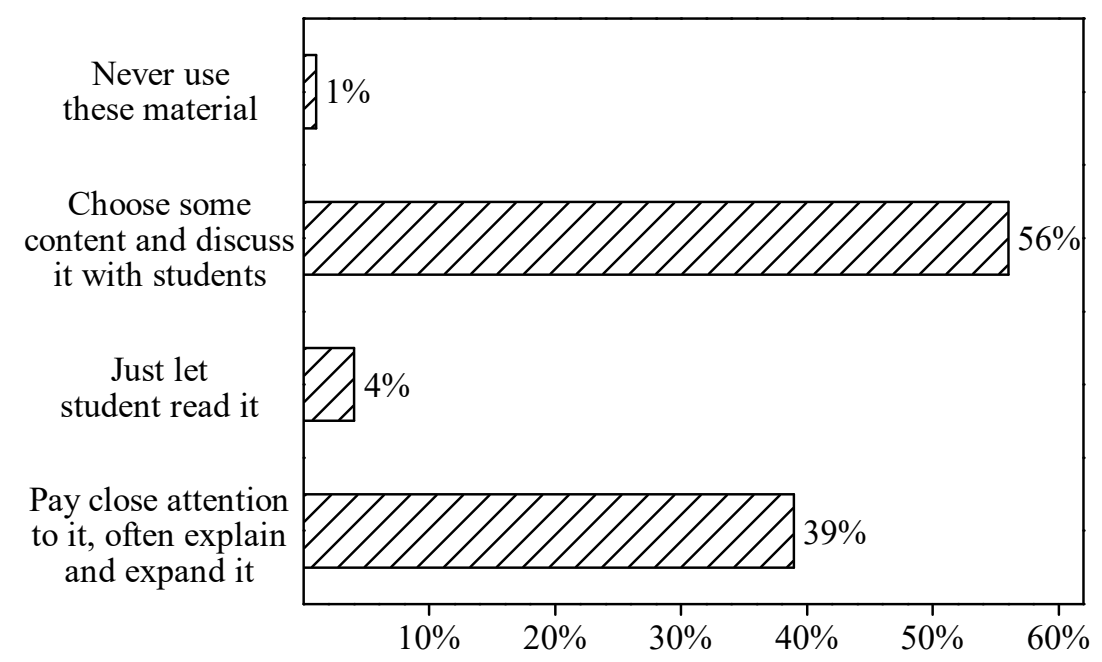

Figure 4. How to use activities and reading material in textbook.

Third, teachers with more than 10 years' experience were able to organize freely and teach the required content (Figure 5). These teachers didn't, completely follow the textbooks and standards, but they were able to explain the key content at length to their students. This was accomplished through choice and the implementation of their own unique teaching styles. It was also discovered that only about four percent of the participants completely followed the standards and textbooks when teaching SD.

Finally, as is shown in Figure 5, the research found that there may be a correlation between teaching ability for SD and teaching age. Among the groups of student's ages 6-10 and 11-20, were more than twenty teaching groups. The teaching ability increased with years of experience. However, the authors were unable to determine why there was such a high proportion in the $0-5$ teaching age group. In the interviews, the authors also concluded that many new geography teachers were able to use multi-media and website resources. They wanted to teach everything about every topic, however this rarely led to positive student results. Therefore, young teachers were able to understand student' learning levels. For example, one questions was; which knowledge should be supplemented when teaching new courses?

Teaching methods and case studies were the most popular method in implementing SD. As the analysis of Question 15 (Appendix B) illustrated, geography teachers adopted various methods for this implementation. In the interviews, some teachers said they organized student debating contests or presented videos related to SD, and then let the students narrate and talk about their experience. 


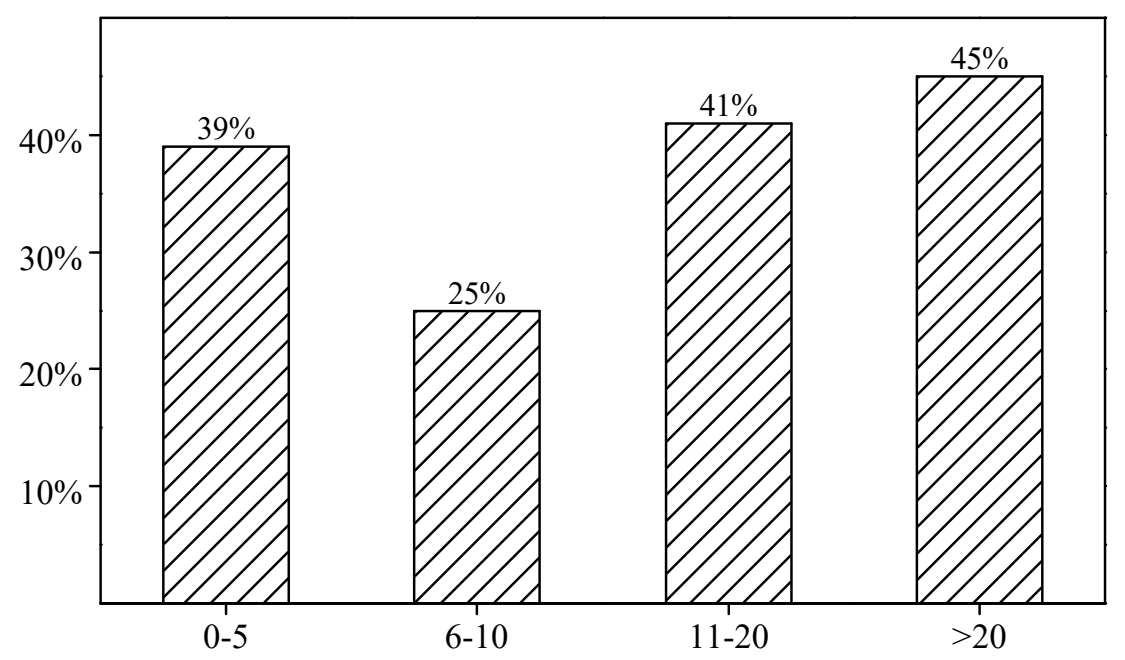

Figure 5. Ratio of teachers who could organize/add freely to the SD content based on their teaching practice and experience for different teaching age groups.

There remain challenges for SD in geography. For example, formalism in the implementation of SD in geography teaching and lack of systematic SD knowledge by teachers, were issues that still need to be addressed. Many challenges were seen in the questionnaire and in the interviews. For example,

Participant 20 said "teaching resources are not enough, and content about SD is unclear, the students are not interested in old material"; Participant 217 said" Learning and life is out of touch, while talking about sustainable lifestyle, students still use disposable chopsticks."

Finally, the survey item of "studying new and effective ideas of SD" was shown to be the most effective way to improve teachers' teaching abilities. Nearly thirty percent of the participants (Figure 6) selected this option. Twenty-nine percent of participants illustrated that geographic information technology and other information communication technology was also an important way to improve teaching ability about SD. In addition, the research found that teacher education and peer communication were also considered effective. There were also other suggestions, for example, geography teachers should increase their study efforts regarding the curriculum standards and textbooks. The teachers should contribute more effort when presenting material regarding SD and interdisciplinary SD teaching.

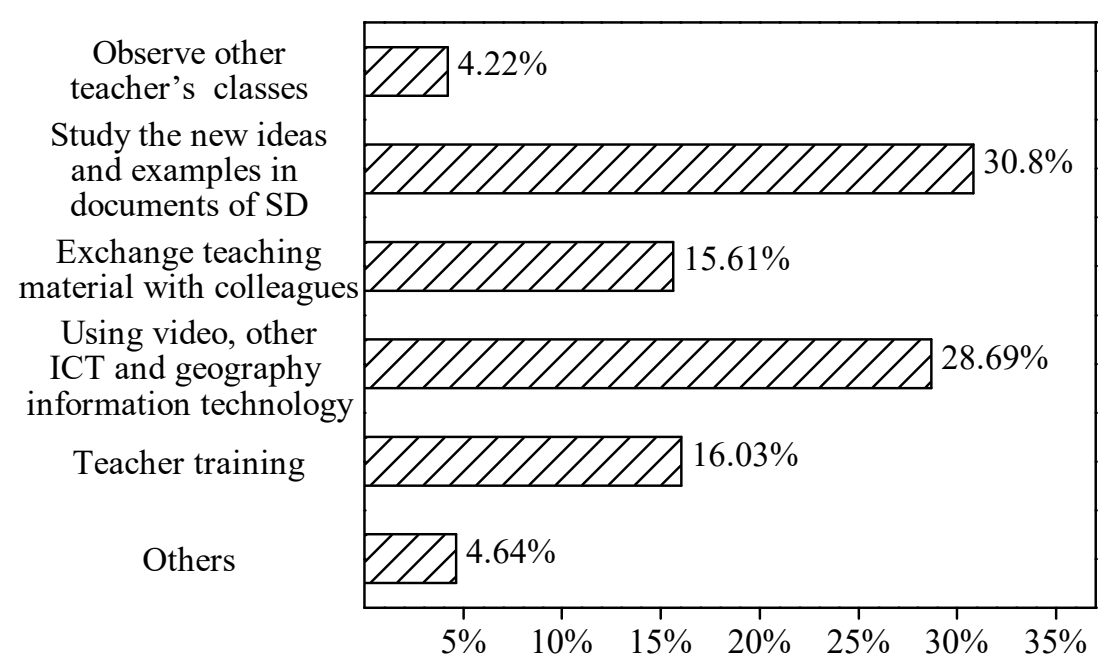

Figure 6. Effective ways for teacher's SD capability. 


\subsection{Students' Sustainable Development Capability in the Middle School}

The test results illustrated student's performance as currently being "OK." The results also illustrated that students did have a basic conception of SD, however there was still room for improvement. Eighty-three percent of the respondents earned a passing score, twenty-eight percent of which were considered "good." The highest score was 74, and the lowest score was 0 . The difficulty index of the test was 0.38 ; which meant that the examination was not easy for the students.

The discrimination index of most items were more than 0.4. This means the discernment of questions were very good (Appendix D). However, Item 1.1 and Item 2.4 were lower than 0.2 (Table 3), therefore, the discernment of these questions was not considered good. One potential reason for these lower scores may be related to the inability to sort the instability factors that influence SD (Item 1.1 in Figure 7). In Item 2.4, the difficulty index may be higher than it should be (Item 2.4 in Figure 7). Most students did not know the exact temperature rise or the sea-level rise caused by climate change at the end of 21 Century.

Table 3. The Item discrimination index.

\begin{tabular}{ccc}
\hline ITEM & Pearson Correlation & Sig. (2-tailed) \\
\hline 1.1 & 0.073 & 0.257 \\
2.4 & $0.137^{*}$ & 0.031 \\
\hline
\end{tabular}

* Correlation is significant at the 0.05 level (2-tailed).

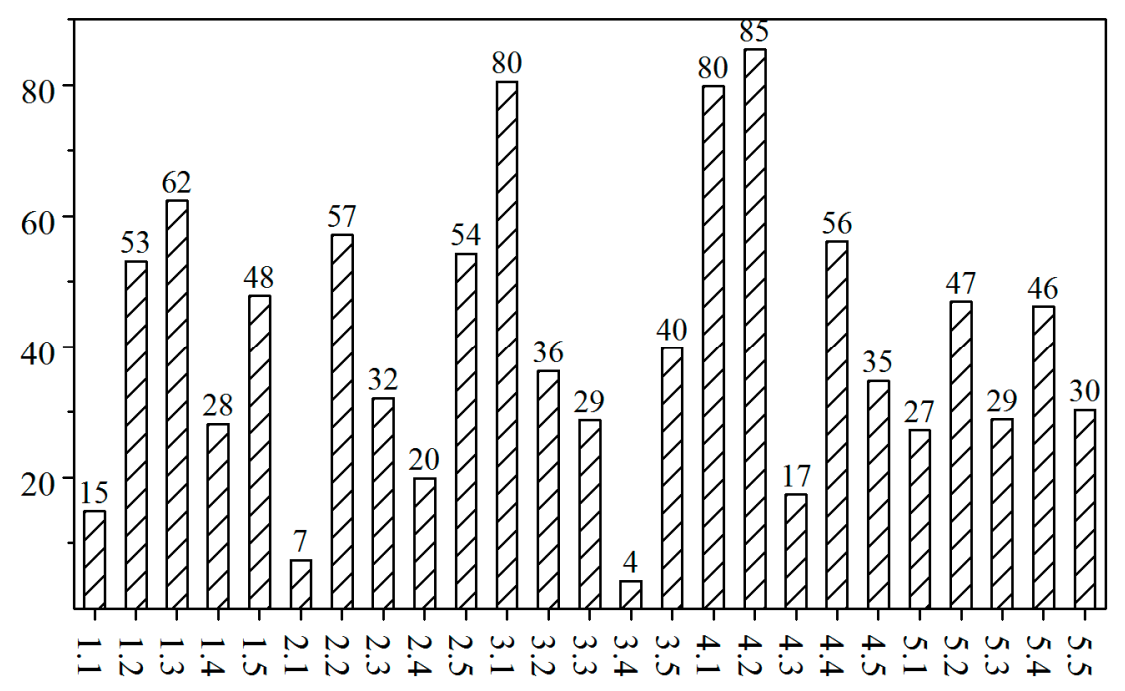

Figure 7. The difficulty index of all the items.

Many students hold the misconception that global warming is the primary cause for all global change. Essentially, students could not understand the impact of several factors regarding the world's instability. For example, in Item 1.1, about five percent of the students were able to sort the factors correctly. Around nineteen-percent of the students knew that both natural and anthropogenic catastrophes were the most important factors that affected the world's instability.

First more than eighty percent of students correctly identified an SD indictor and listed the SD problems from local to global in terms of scale (Item 3.1, 4.1, and 4.2 in Figure 7). However, only slightly more than half of the students could explain the global problem more clearly (Item 4.4 in Figure 7). While most of the students could not fully and reasonably explain the problem, some students gave more interesting answers in Item 4.4. Item 4.4 states: Give a short description of a global problem using the following questions: (1) What are the basic causes? (2) Is it typical of your country? (3) Can it be solved and how? (Both locally and globally) For example: 
Participant 65: "(1) Issues 17, save forest; this is caused by the pursuit of economic growth, and deforestation; (2) This is a typical problem in China; (3) From the perspective of the world, the United Nations should formulate laws and regulations to restrain countries from over foresting. In addition, our country should make laws and regulations and strictly supervise the implementation of these laws and regulations."

Second, most students were familiar with people, resources, environmental problems, and climate change, however many of the participants could still benefit from improvement in their knowledge of SD. In the test, more than half of the students answered correctly for Items 1.2, 1.3, and 2.2, 2.5 (see Figure 7). Item 1.2 is about population, and most students were able to provide the correct answer ("uneven distribution of wealth inside the country, poverty"). Many of the students were able to write "overpopulation and/or migration." In addition, many of the students were able to supplement other correct answers such as "population growth, low population quality, gender ratio imbalance, and aging." According to Item 2.2 and Item 2.5, students believed that climate change could cause a lot of problems. For example,

Participant 162 reported: "the change of grain output may be the cause for food shortage. As well as a lot of climate refugees seeking shelter from EI Nino and extreme weather events. However, when asked about the causes of climate change, most of students were only able to identify two factors. One individual indicated: increasing amounts of greenhouse gases and deforestation. None of the students answered with the following statement: "increasing the amount of atmospheric aerosols;" This could be due to the fact that the standards and textbooks did not address these issues.

Some students had a dialectical view on the relationship between social economic development and ecological environment (Item 4.5). For example,

Participant 88 reported: "the initial development of the social economy depends on nature. After industrialization, economic development, has caused more and more ecological problems. The development of world politics affects the development of economy."

Third, most students were unable to grasp the factual knowledge about SD, such as international events and documents, and the examples of indicators used to assess additional aspects of SD. As shown in Figure 7, the difficulty index of Item 3.4 and 2.1 was less than ten-percent. This inferred that less than ten participants in one hundred, indicated the correct answers for these items. Item 3.4 describes the example of SD indicators, which is the lowest score in the questionnaire, having an average score of 0.21 (Table 4). The total score is 5 . While the students scored highest in Item 3.1 (identify the main SD indicator), most of the students left Item 3.4 blank. Perhaps the students did not know the specific indicators (coefficients, indexes) to assess SD. Some of the students simply used words to explain the various indicators or they provided a vague answer; such as Engel coefficient, CPI, Green GDP, and ecological footprint. For Item 2.1, there were 213 student participants that knew nothing of the international documents regarding SD (published in 1992, 2002, and 2012). Several students were able to write other documents, such as Kyoto Protocol and Copenhagen Accord. It should be noted that none of students were able to complete all the information correctly.

Table 4. The Descriptive statistics of Item 3.4.

\begin{tabular}{ccccccc}
\hline \multirow{2}{*}{ Item } & $\mathbf{N}$ & Minimum & Maximum & \multicolumn{2}{c}{ Mean } & \multicolumn{2}{c}{ Std. Deviation } \\
\cline { 2 - 7 } & Statistic & Statistic & Statistic & Statistic & Std. Error & Statistic \\
\hline 3.4 & 246 & 0 & 3 & 0.21 & 0.035 & 0.553 \\
Valid N (listwise) & 246 & & & & & \\
\hline
\end{tabular}




\section{Discussion}

UNESCO defines Education for Sustainable Development (ESD) “as means of addressing present and future worldwide challenges by creating sustainable and resilient societies. ESD content and approaches have been applied throughout the tertiary curriculum but one area that lags is English as a Foreign Language (EFL)." [42] This research has addressed the missed opportunity in countries like China, where students in higher education have limited exposure to environmental topics. This research has aimed to contribute to the broader understanding of themes and patterns within the standards and textbooks used in Chinese middle schools.

As mentioned above, ideas of SD were identified in geography standards and textbooks, however the implementation was not optimal. This is primarily because geography has not paid enough attention to the subject areas of the high school entrance exams. The research illustrated the importance for students to understand the significance of SD. Furthermore, the content regarding SD were not specific. This made teachers and students think abstractly, however they rarely talked about it. In the authors' opinion, geography standards, and geography textbooks should pay more attention to SD issues. A geography teacher should expand their knowledge about SD for a deeper level of teaching and learning.

The authors' have identified several suggestions to improve the quality of SD in geography education.

First, in the lead author's opinion, the most appropriate content and the most appropriate resources of SD were not integrated well into the geography curriculum. Many global and/or local problems could be better guided from geographic perspectives. For example: "Where is it? What is it like? Why is it there? How did it happen? What impact does it have? How should it be managed for the mutual benefit of humanity and the natural environment?" [43]. Per reports and documents in China and other countries, we can update the content about SD. This is especially true in terms of multimedia resources, which were highly supported by teachers within the survey. In addition, it may be a good idea to develop a school-based curriculum about SD, which would complement the standards and textbooks. This informational knowledge can be added into the man-nature's short history about SD, which is meaningful. Additionally, independent chapters about SD can be developed in the geography textbooks.

Second, many teachers in the survey believed that the best way of teaching was to provide students with more practical activities and a chance to participate in hands-on experiments, as well as building student organizations and clubs. For example, teacher $(X)$ said "Students can get close to nature, experience life and develop new ideas of SD, or, teachers can collaborate with other teachers to organize visits to a museum. Collaboration can lead to increased value in field-work learning. By participating in these practice activities, students were able to realize that human beings are not the masters of nature but are simply a part of nature. Humans should not only learn to respect nature and reverence for life, but also should have morality and responsibility of protecting and improving the environment.

Third, develop SD training programs for geography teachers. Every geography teachers' knowledge and understanding were immensely important to their success as an educator. As shown in Figure 7, over fifteen percent of the teachers needed additional training. Therefore, teacher education, supporting new teachers and career professional development activities are an excellent basis for providing high-quality education in SD.

Forth, building a platform for communicating ideas of SD in different ways, especially modern communication technology. For example, $\mathrm{QQ}$ and WeChat in China are popular social software with more than one-billion users. These social organizations, along with the teachers, can create Official Regulations that infuse the ideas of SD into geography curriculum. The SD content should be interesting with less text, and more exciting videos from scientific sources; such as Chinese National Geography, National Geographic, research report, etc. Mobile apps and computer games are also useful ways to educate the worldwide population on SD. Modern technologies have changed both 
student populations and overall education dramatically. Today's students are no longer the people our educational system was designed to teach [44]. Inventing and improving educational video games will be a progressive way to improve students' ideas of SD.

Lastly, ideas of SD should be integrated into students' daily life. Most of the time a student's lifetime is spent outside of the classroom. Ideas of SD can be integrated into daily life in more discrete ways. TV, canteen, public transportation services are excellent methods in exerting a subtle influence on people's behavior.

Developing public advertising by internet, radio, television, or in public places will be useful in building awareness of SD. The content can be based on the sorts of social, economic, and environmental issues faced both locally and globally. For example, green commuting, endangered species, and water pollution are directly related and highly important to teaching and learning of SD.

\section{Conclusions}

This research has identified two major concerns. The first concern is that the standards, especially in Chinese middle school textbooks, may lack sound content and knowledge of SD. This is the case in China and it seems reasonable to assume that this may be a problem in other countries. The second concern is that ESD in geography has a problem of formalism, in the form of doctrine. Teachers lack systematic knowledge and support within the implementation of SD. Students know little about international efforts and statistics for SD, and students' SD capabilities need to improve because the results of test were not positive.

The basic knowledge and theories regarding SD, such as fundamental ideals, basic documents, indicators, theoretical knowledge, and empirical knowledge for SD were not mentioned in the textbooks. The content associated with SD were brief and were only mentioned in the "activities and reading material" section of the textbook, which may be neglected by teachers and students. In addition, due to lack of appropriate assessment about SD, the school leaders and teachers paid little to no attention to the instruction of SD. These concerns raised questions about young student's knowledge of SD. It is important to note that schooling empowers students to develop their best understanding to be informed members of their local, national, and international communities.

This research analyzed the geographical knowledge and content that contributed to SD in geography standards and textbooks of China. The research inquired as to how geography teachers fostered students' SD abilities and assessed 16-year-old students with a test. Regarding problems with the implementation, the authors attempted to provide some suggestions and recommendations to improve SD in geography in accordance with the realities of life in China. The recommendations were given to the Geography Teaching Professional Commission of Chinese Society of Education, and the Panel for Geography Standards Revision. More importantly, this research reinforced the need for more complete and deeper research into the breadth, depth, and prospective of primary teachers' knowledge and understanding. The next step will be to continue researching geography teacher education in the field of SD, as well as supporting career and professional development. All of which are the basis for providing the high-quality education for geography students.

Author Contributions: Conceptualization, J.P.S.; Methodology, O.K.; Validation, F.G., J.L. J.P.S., O.K. and Y.D.; Formal Analysis, F.G. H.L.; Investigation, F.G.; Resources, O.K.; Data Curation, F.G., W.Z.; Writing-Original Draft Preparation, F.G., J.L.; Writing-Review \& Editing, J.L., F.G.; Visualization, F.G.; Supervision, Y.D.

Funding: This research received no external funding.

Acknowledgments: Thank Liqun Zhai, Wenning Duan and Lixia Chang for their help and support during the survey.

Conflicts of Interest: The authors declare no conflict of interest. 


\section{Appendix A}

Table A1. Position of ideas of sustainable development in the content of geography school course.

The main units of the content of geography Issues of the unit connected with the ideas school courses (middle school)

Table A2. Fundamental ideas of sustainable development.

\begin{tabular}{|c|c|c|}
\hline Fundamental Ideas & Detailed Content & $\begin{array}{l}\text { Sections of the Content of } \\
\text { Geography School Courses }\end{array}$ \\
\hline $\begin{array}{l}\text { The Earth is the home of humanity, we have to take } \\
\text { care of it together }\end{array}$ & & \\
\hline $\begin{array}{l}\text { The Earth is given to us and to the future generations, } \\
\text { we have to be responsible for the use and } \\
\text { enhancement of its riches }\end{array}$ & & \\
\hline $\begin{array}{l}\text { Sustainable development is based on balance of } \\
\text { economic, ecological and social interests of society }\end{array}$ & & \\
\hline $\begin{array}{l}\text { Sustainable development is the only strategy which } \\
\text { makes survival of humanity on Earth possible }\end{array}$ & & \\
\hline
\end{tabular}

Table A3. Basic documents on sustainable development in the content of geography school courses (middle school).

\begin{tabular}{|c|c|c|}
\hline List of Documents & Detailed Content & $\begin{array}{l}\text { Sections of the Content of } \\
\text { Geography School Courses }\end{array}$ \\
\hline $\begin{array}{l}\text { World strategy of nature conservation (Ashgabat, } \\
\text { 1979) }\end{array}$ & & \\
\hline World charter of nature (1982) & & \\
\hline $\begin{array}{l}\text { Rio declaration on environment and development, } \\
\text { Action program. The agenda for the XXI century, } \\
\text { Convention on biodiversity (1992, Rio de Janeiro) }\end{array}$ & & \\
\hline $\begin{array}{l}\text { Political declaration on sustainable development, } \\
\text { Plan of implementation of solutions of the World } \\
\text { summit for sustainable development (2002, } \\
\text { Johannesburg) }\end{array}$ & & \\
\hline The future we want (2012, Rio de Janeiro) & & \\
\hline
\end{tabular}

Table A4. Instruments of interstate regulation for sustainable development.

\begin{tabular}{|c|c|c|}
\hline Instruments of Interstate Regulation & Detailed Content & $\begin{array}{l}\text { Sections of the Content of } \\
\text { Geography School Courses }\end{array}$ \\
\hline $\begin{array}{l}\text { 1. Implementation of international investments and } \\
\text { credits (the largest creditors-the World bank, the } \\
\text { International bank of reconstruction and } \\
\text { development, the International Monetary Fund } \\
\text { submit to recommendations of the UN) }\end{array}$ & & \\
\hline $\begin{array}{l}\text { 2. Economic and political isolation of the state } \\
\text { (caused by the introduction of restrictive conditions } \\
\text { of the World Trade Organization before the economic } \\
\text { blockade of the state by the UN) }\end{array}$ & & \\
\hline
\end{tabular}


Table A4. Cont.

\section{Instruments of Interstate Regulation}

3. Target financial, intellectual and innovative support (grants, new technologies, patents, consultations of experts)

4. Obligatory ratification of Contracts and Conventions

5. Control through the special Commissions and remotely

Table A5. Indicators of sustainable development.

\begin{tabular}{|c|c|c|}
\hline Indicators & Detailed Content & Sections of the Content of Geography School Courses \\
\hline \multicolumn{3}{|l|}{ 1. Social } \\
\hline \multicolumn{3}{|l|}{ 2.Ecological } \\
\hline \multicolumn{3}{|l|}{ 3. Economic } \\
\hline 4. Institutional & & \\
\hline
\end{tabular}

Table A6. Fundamental issues/subjects/problems.

\begin{tabular}{|c|c|c|}
\hline Fundamental Issues/Subjects of a Sustainable Development & $\begin{array}{l}\text { Detailed } \\
\text { Content }\end{array}$ & $\begin{array}{l}\text { Sections of the Content of } \\
\text { Geography School Courses }\end{array}$ \\
\hline \multicolumn{3}{|l|}{ 1. Poverty eradication } \\
\hline \multicolumn{3}{|l|}{ 2. Food security } \\
\hline \multicolumn{3}{|l|}{ 3. Water supply and sanitation } \\
\hline \multicolumn{3}{|l|}{ 4. Power } \\
\hline \multicolumn{3}{|l|}{ 5. Sustainable tourism } \\
\hline \multicolumn{3}{|l|}{ 6. Transport meeting the requirements of stability } \\
\hline \multicolumn{3}{|l|}{ 7. Cities and settlements meeting the requirements of stability } \\
\hline \multicolumn{3}{|l|}{ 8. Health care and population } \\
\hline \multicolumn{3}{|l|}{ 9. Employment, adequate work, social protection } \\
\hline \multicolumn{3}{|l|}{ 10. World Ocean } \\
\hline \multicolumn{3}{|l|}{$\begin{array}{l}\text { 11. Regional interests (small island developing states; least } \\
\text { developed countries; developing countries which don't have an } \\
\text { outlet to the sea; Africa; regional efforts) }\end{array}$} \\
\hline \multicolumn{3}{|l|}{ 12. Disaster reduction } \\
\hline \multicolumn{3}{|l|}{ 13. Climate change } \\
\hline \multicolumn{3}{|l|}{ 14. Woods } \\
\hline \multicolumn{3}{|l|}{ 15. Biodiversity } \\
\hline \multicolumn{3}{|l|}{ 16. Desertification, degradation of lands, drought } \\
\hline \multicolumn{3}{|l|}{ 17. Mountainous areas } \\
\hline \multicolumn{3}{|l|}{ 18. Chemical substances } \\
\hline \multicolumn{3}{|l|}{ 19. Rational models of consumption and production } \\
\hline 20. Production of natural resources & & \\
\hline
\end{tabular}


Table A7. Theoretical knowledge of sustainable development.

\begin{tabular}{|c|c|c|}
\hline Theoretical Knowledge & Detailed Content & Sections of the Content of Geography School Courses \\
\hline \multicolumn{3}{|c|}{ 1. Doctrines, theories, regularities } \\
\hline \multicolumn{3}{|l|}{ 2. Hypotheses } \\
\hline 3. Concepts & & \\
\hline
\end{tabular}

Table A8. Empirical knowledge of sustainable development.

\begin{tabular}{|c|c|c|}
\hline Empirical Knowledge & Detailed Content & $\begin{array}{l}\text { Sections of the Content of } \\
\text { Geography School Courses }\end{array}$ \\
\hline 1. Facts & & \\
\hline 2. Figures & & \\
\hline 3. Examples of the countries, cities, regions & & \\
\hline
\end{tabular}

Table A9. Aspects of education, important for geography and for sustainable development.

\begin{tabular}{|c|c|c|}
\hline Aspects & Detailed Content & $\begin{array}{l}\text { Sections of the Content of } \\
\text { Geography School Courses }\end{array}$ \\
\hline \multicolumn{3}{|l|}{$\begin{array}{l}\text { 1. Environmental management, resource depletion, } \\
\text { environ-mental pollution }\end{array}$} \\
\hline \multicolumn{3}{|l|}{$\begin{array}{l}\text { 2. Growth of the population, development of } \\
\text { economy, escalation of regions and countries } \\
\text { inequality }\end{array}$} \\
\hline \multicolumn{3}{|l|}{$\begin{array}{l}\text { 3. A place as a focus of interaction and contradictions } \\
\text { in The Nature-Economy-Population system }\end{array}$} \\
\hline \multicolumn{3}{|l|}{$\begin{array}{l}\text { 4. Interrelations in The } \\
\text { Nature-Economy-Population system at global, } \\
\text { national, regional level }\end{array}$} \\
\hline \multicolumn{3}{|l|}{$\begin{array}{l}\text { 5. The conflicts concerning ecological, economic and } \\
\text { social stability and arising due to the contradictory } \\
\text { purposes }\end{array}$} \\
\hline \multicolumn{3}{|l|}{ 6. Risks and their prevention } \\
\hline$\ldots$ & & \\
\hline
\end{tabular}

Table A10. Methods and approaches on geographical education for sustainable development.

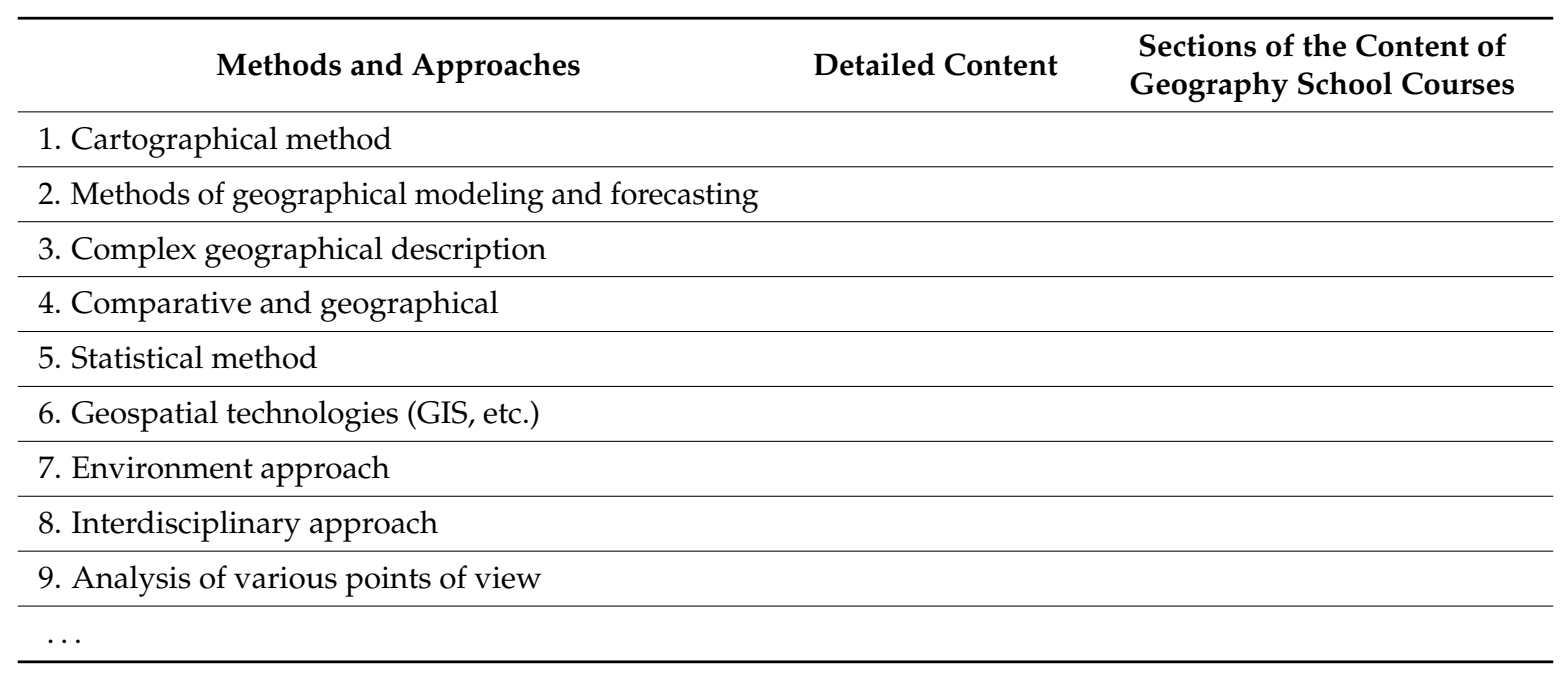




\section{Appendix B}

Questionnaire for geography teachers

Introduction:

This questionnaire is for teacher who teach geography in middle school. we are interested in learning about implementation of sustainable development in geography, needs and suggestions of teacher.

Your responses are voluntary and confidential. Your answer may be used only of statistical purpose and may not be disclosed, or used, in identifiable form for any other purpose.

Most question can be answered by marking the one most appropriate answer. It is estimated that it will require approximately $20 \mathrm{~min}$ to complete this questionnaire. Thank you for the thought, time and effort you have put into responding to this questionnaire. We greatly appreciate your contribution to the study.

When in doubt about any aspect of the questionnaire, or if you would like more information about the questionnaire or the study, you can reach us by email ...

Thank you.

Background Information

(these question are about you, you education, teacher and the textbook you used. In responding to the question, please mark the appropriate choice or provide the figure when necessary).

1. Are you female or male?

$\square 1$ Female $\square 2$ Male

2. Which province or city are you come from?

3. What is the highest level of formal education you have completed?

$\square 1$ College's degree or below

$\square 2$ Bachelor's degree

$\square 3$ Master's degree

$\square 4$ Doctoral degree or equivalent

4. What is your specialty?

$\square 1$ Geography $\square 2$ Social studies/Social science $\square$ 3 Science $\square 4$ Other subject

5. By the end of this school year, how many year will you have been teaching altogether (geography)?

$$
\text { years }
$$

6. Which version of geography textbook you used?

$\square$ People's Education Press $\square 2$ Other Publishing house

\section{QUESTIONS ABOUT SUSTAINBALE DEVELOPMENT}

The sustainable development in standards, Textbook and your preparation.

7. There are clearly explain the Ideas of Sustainable Development (SD) in geography standard. 
$\square 1$ Yes $\square 2$ No

8. You can identify the contents about SD in geography standard and textbook.

$\square$ Strongly disagree $\square 2$ Disagree $\square 3$ Agree $\square 4$ Strongly agree

9. You are familiar with the related contents and ideas of SD.

$\square 1$ Strongly disagree $\square 2$ Disagree $\square 3$ Agree $\square 4$ Strongly agree

10. While prepare lessons, you think how to cultivate the students' ideas of SD.

$\square 1$ Always $\square 2$ Often $\square 3$ Sometime $\square 4$ Never How do the teachers deal with content and methods of SD in teaching process?

11. In geography class, you teach the content of SD

$\square 1$ Follow the standard and textbook

$\square 2$ Add other material appropriately besides follow the standard and textbook

$\square 3$ Organize/add freely the content based on teaching practice and experience

12. Regarding theoretical knowledge about SD in geography class, you have taught or discussed (multiple choice)

$\square 1$ Definition of SD

$\square 2$ Main ideas of SD

$\square 3$ Basic principle of SD

$\square 4$ Indicator of SD

$\square 5$ Main documents of SD

$\square 6$ Key questions of SD

$\square 7$ Other, please specific

13. Regarding reading material in textbook, you usually

$\square 1$ Pay close attention to it, often explain and expand it.

$\square 2$ Choose some content and discuss it with students

$\square 3$ Just let student read it

$\square 4$ Never use these material

14. You organize and develop the activities in geography textbook

$\square 1$ Always $\square 2$ Often $\square 3$ Sometime $\square 4$ Never

15. Which activities you used to cultivate the students' ideas of sustainable development?

$\square 1$ Seminar $\square 2$ Give a speech $\square 3$ Investigation

$\square 4$ Write a thesis $\square 5$ Role play $\square 6$ Discussion

$\square 7$ Other, please write

16. You used knowledge or principle of other subjects when you teaching SD in geography.

$\square 1$ Always $\square 2$ Often $\square 3$ Sometime $\square$ 4 Never

Some personal perspective about SD in geography

17. Which is most effective for sustainable development in geography education for you? 
$\square 1$ Observe other teacher's classes

$\square 2$ Study the new ideas and examples in documents of SD

$\square 3$ Exchange teaching material with colleagues

$\square 4$ Using video, other ICT and geography information technology

$\square 5$ Teacher training

$\square 6$ Others, please write

18. List the main ideas of "sustainable development" which you consider as the most important for teaching

19. Which problems about geography education for SD in middle school, and what's your suggestion?

This is the end of the questionnaire.

Thanks again for your participation and cooperation!

\section{Appendix C}

Test for students

Dear participates, the survey aims at assessing SD knowledge and skills. The results will be used only for research and statistic goals. The test includes 5 modules, each contains an introductory text with tasks that need a free and precise response. The maximum number of points for all is 100 (two points is given for each tasks)

Thank you for your ideas, time and efforts. We appreciate your contribution to the research. Appeal to organizers if necessary.

Before beginning, please, write down some of your personal info:

1. Gender

2. Age

3. Country, locality

4. Institute

5. Full name (unnecessary)

NOTE: Read the introductory text before you do the task. Then read the task. Do not rewrite them. Please, put down the number of the question and give a short answer on your form.

We wish you good luck!

Part 1

The Future of the Earth

The Earth is an integral part of universe. Its future is determined by space processes such as formation of new galaxies or their clusters, collision with comets and asteroids, increase of solar activity and others. However, in foreseeable future the existence of the planet and humanity depends on the ability of the world community to keep social, economic and ecological aspects of the evolution under control. According to scientists, the main reasons for "instability" are

A. Climate changes and decrease of biodiversity

B. Catastrophes (both natural and anthropogenic) 
C. Demographic changes

D. Production and emission of contaminants, depletion of resources

Tasks:

1.1. Place the instability factors according to their impact on sustainable development (please start with the most significant one).

1.2. Enumerate the most important demographic changes bringing to social instability.

1.3. Fill in the gaps:

Factors of fluctuation need (1) (2) of future, and (3) of the world community to realize the most (4) ___ scripts of sustainable development—conscious control over interaction between mankind and nature.

1.4. Enlist examples of utopic and realistic "scripts" of human future.

1.5. Describe the most realistic "script". What types of interaction does it include?

Part 2

International cooperation

The World's Summit held in New York in September 2015, defined "the road map for mankind, planet and prosperity". The Resolution of UN(O) Transforming our world: the 2030 Agenda for Sustainable Development pointed out 17 primary goals of sustainable development:

Goal 1. End poverty in all its forms everywhere

Goal 2. End hunger, achieve food security and improved nutrition and promote sustainable agriculture

Goal 3. Ensure healthy lives and promote well-being for all at all ages

Goal 4. Ensure inclusive and equitable quality education and promote lifelong learning opportunities for all

Goal 5. Achieve gender equality and empower all women and girls

Goal 6. Ensure availability and sustainable management of water and sanitation for all

Goal 7. Ensure access to affordable, reliable, sustainable and modern energy for all

Goal 8. Promote sustained, inclusive and sustainable economic growth, full and productive employment and decent work for all

Goal 9. Build resilient infrastructure, promote inclusive and sustainable industrialization and foster innovation

Goal 10. Reduce inequality within and among countries

Goal 11. Make cities and human settlements inclusive, safe, resilient and sustainable

Goal 12. Ensure sustainable consumption and production patterns

Goal 13. Take urgent action to combat climate change and its impacts

Goal 14. Conserve and sustainably use the oceans, seas and marine resources for sustainable development

Goal 15. Protect, restore and promote sustainable use of terrestrial ecosystems, sustainably manage forests, combat desertification, and haltand reverse land degradation and halt biodiversity loss

Goal 16. Promote peaceful and inclusive societies for sustainable development, provide access to justice for all and build effective, accountable and inclusive institutions at all levels

Goal 17. Strengthen the means of implementation and revitalize the Global Partnership for Sustainable Development

Tasks:

2.1. Most of goals were discussed earlier. Fill in the Table A11 below with main events in SD. 
Table A11. Main events in sustainable development.

\begin{tabular}{cccc}
\hline Year & Event & Location & Documents \\
\hline 1992 & & & \\
2002 & & & \\
2012 & & & \\
\hline
\end{tabular}

2.2. In December 2015 the World Summit in Paris dealt with urgent measures to combat climate change (goal 13). Write down the number of SD goals (see the text) mostly associated with climate change.

2.3. Intergovernmental climate change expert group released data declaring that the world's average temperature increased by $0.85{ }^{\circ} \mathrm{C}$ between 1880 and 2012. Write down the main anthropogenic reasons for that.

2.4. Several scenarios exist depending on rate of global warming. Fill in the gaps in text below:

According to the latest data the world's temperature will increase by (1) ${ }^{\circ} \mathrm{C}$ by the end of XXI century if no urgent measures are taken. As well as the temperature of the ocean will rise, ice caps will continue melting. The average sea level will go upby (2) $\mathrm{m}$. Most consequences of climate changes will remain for centuries.

2.5. Explain the way the world temperature affects mankind.

Part 3

\section{Ecological footprint}

How can we assess anthropogenic impact on our planet? What can we do to reduce it?

Canadian scientists W. Riss and M. Walkernegel were the first to dwell on it in their book "Our ecological footprint" in 1996. They offered a method to calculate the square of biologically productive territory and water area needed to produce resources consumed by man as well as to annihilate and recycle our waste. According to the latest recalculation, the square is 1.8 gha/pers a year while the total population is about 6 billion.

According to UN 2009 data, human needs (our ecological footprint) are 1, 4 higher than the planet's capacity and equal to 2.6 gha / pers. States form their own "footprint" differently.

Here are the average ecological footprints (gha/pers) for some countries:

UAE-10.3, Qatar-9.9, USA-9.0, New Zealand-7.6, Great Britain-6.1, Switzerland-5.6, Russia—4.4, Kazakhstan—4.4, Germany-4.0, Ukraine-2.7, China-1.8, Uzbekistan-1.7, Somali-1.5, Congo-1.0, Vietnam-1.0, India-0.8, Venezuela-0.5.

The value of the ecological footprint means wherever a country has (or does not have) ecological resources enough to provide social standards of living, and is also a criterion to define "countries-debtors" and "countries-creditors".

Tasks:

3.1. Define the indicator group described in the text:
A. Social
B. Economic
C. Ecological
D. Institutional

3.2. Group out the countries mentioned in text in two groups according to their part in consuming ecological resources:
A. "countries-debtors"
B. "countries-creditors" 
3.3. Define the number of your country's ecological footprint. Compare it to the planet's capability and to other countries' footprints. Draw a conclusion. Explain what this number is formed by.

3.4. Give examples of indicators (coefficients, indexes) used to assess different SD aspects.

3.5. Modern ecological footprints on-line-calculators deal with different aspects of human life that influence our planet, including consumption of food, power sources, transport and others. Suggest ways of its reducing.

Part 4

SD key issues

International documents determine key issues necessary for sustainable development of humanity:

End poverty in all its forms everywhere

End hunger, achieve food security and improved nutrition and promote sustainable agriculture

Ensure availability and sustainable management of water and sanitation for all

Ensure access to affordable, reliable, sustainable and modern energy for all

Eco-tourism

Eco-transport

Cities built by terms of SD

Public health service

Promote sustained, inclusive and sustainable economic growth, full and productive employment and decent work for al

Save ocean

Save sea-locked states

Help emerging nations

Africa

Local efforts

Lower disaster impact

Lower climate changes

Save forest

Save biodiversity

Lower the speed of desertisation, land degradation and drought

Help mountainous area

Lower chemical waste

Rational model of consumption and production

Improve upstream

Ensure inclusive and equitable quality education and promote lifelong learning opportunities for all

Achieve gender equality and empower all women and girls

Tasks:

4.1. Mark numbers of global problems from the list above which you think should be the first on the line to solve.

4.2. Put down (with their numbers from the list above) the problems most urgent in your country.

4.3. Explain how much solving global problems can affect every single human.

4.4. Give a short description of a global problem using the following questions:

(1) What causes it?

(2) Is it typical of your country?

(3) Can it be solved and how? (Both all over the world and your country) 
4.5. Say if the next statement is true or false: "Ecological problems are formed by the society's socio-economic and political development".

\section{Part 5}

Cities with SD principles

Almost 3.5 billion of people live in economically, scientifically, culturally and socially advanced cities. The cities cover 3 per cent of land and are main energy consumers (60-80 per cent) and carbon dioxide suppliers (about 75 per cent).

Most cities have the following common problems such as:

Overpopulation

Shortage of funds

Housing demand

Retrogression of infrastructure

SD index can be used to assess positive (and negative) changes in urban life. SD index allows to describe quantitative changes on next criteria:

Subjective well-being

Efficiency of resources use

Purity of environment

Cities infrastructure

$\mathrm{SD}$ in future

There are many cities with SD principles all over the world. In China, Leading positions in the Sustainable Cities in the eastern part of China. In 2013 China Sustainable index report, Top-10 was presented by capitals (Beijing, Hangzhou, Changsha), coastal cities (Dalian, Xiamen, Yantai), central cities of regions (Shanghai, Guanzhou).

Tasks:

5.1. Which of the problems mentioned in the text above (A-D) are typical of your city?

5.2. The Table below describes 3 criteria used to form SD cities index (from the list $1-5$ in the text above). Fill in the Table A12.

Table A12. Three criteria used to form sustainable development cities index.

\begin{tabular}{ll}
\hline Criterion & \multicolumn{1}{c}{ Comment } \\
\hline $\begin{array}{l}\text { Efficiency of municipal service (including water and power usage), waste treatment based on } \\
\text { "reduction, recycling and utilization" }\end{array}$ \\
\hline Access to safe drinking water, enough floor space, qualitative public health service and education \\
\hline $\begin{array}{l}\text { Access for all citizens to "green" area, public service vehicle and qualitative rationally built } \\
\text { housing }\end{array}$ \\
\hline
\end{tabular}

5.3. Comment on the other two criteria off the table (from the list $1-5$ in the text above).

5.4. Say what unites cities that have leading positions in the China Cities Ranking List.

5.5. What is "comprehensive strategy" for planning and building SD cities from the standpoint of (1) metropolis citizen, (2) ecologist?

Thanks for cooperation! 


\section{Appendix D}

Table A13. The Item discrimination index for 246 students.

\begin{tabular}{ccc}
\hline Item & Pearson Correlation & Sig. (2-Tailed) \\
\hline 1.1 & $0.073^{* *}$ & 0.257 \\
1.2 & $0.438^{* *}$ & 0.000 \\
1.3 & $0.553^{* *}$ & 0.000 \\
1.4 & $0.473^{* *}$ & 0.000 \\
1.5 & $0.614^{* *}$ & 0.000 \\
2.1 & $0.283^{* *}$ & 0.000 \\
2.2 & $0.365^{* *}$ & 0.000 \\
2.3 & $0.575^{* *}$ & 0.000 \\
2.4 & $0.137^{*}$ & 0.031 \\
2.5 & $0.619^{* *}$ & 0.000 \\
3.1 & $0.501^{* *}$ & 0.000 \\
3.2 & $0.497^{* *}$ & 0.000 \\
3.3 & $0.597^{* *}$ & 0.000 \\
3.4 & $0.307^{* *}$ & 0.000 \\
3.5 & $0.687^{* *}$ & 0.000 \\
4.1 & $0.613^{* *}$ & 0.000 \\
4.2 & $0.618^{* *}$ & 0.000 \\
4.3 & $0.668^{* *}$ & 0.000 \\
4.4 & $0.828^{* *}$ & 0.000 \\
4.5 & $0.730^{* *}$ & 0.000 \\
5.1 & $0.547^{* *}$ & 0.000 \\
5.2 & $0.506^{* *}$ & 0.000 \\
5.3 & $0.571^{* *}$ & 0.000 \\
5.4 & $0.774^{* *}$ & 0.000 \\
5.5 & $0.708^{* *}$ & 0.000 \\
\hline
\end{tabular}

* Correlation is significant at the 0.05 level (2-tailed). ${ }^{* *}$ Correlation is significant at the 0.01 level (2-tailed).

\section{References}

1. Guo, F.T.; Stoltman, J.P.; Duan, Y.S.; Bourke, T. A comparison of content standards documents for geographical tuition in China and the United States. Mitteilungen der Osterreichischen Geographischen Gesellschaft 2016, 158, 289-308.

2. The National Development and Reform Commission. The People's Republic of China National Report on Sustainable Development; The National Development and Reform Commission; Ministry of Foreign Affairs; Ministry of Science and Technology: Beijing, China, 2012.

3. Miller, G.T.; Spoolman, S. Environmental Science; Cengage: Boston, MA, USA, 2017.

4. Gro Harlem Brundtland. Our Common Future; World Commission on Environment and Development: Nairobi, Kenya, 1987.

5. Scott, W.; Gough, S. Oral Evidence to the House of Commons Environmental Audit Committee's Enquiry into Sustainable Development; University of Bath: Bath, UK, 2003.

6. China, State Council of the People's Republic of China. China's Agenda 21-White Paper on China's Population, Environment and Development; China, State Council of the People's Republic of China: Beijing, China, 1994.

7. Sustainable Development Education Panel. A Report to DFEE/QCA on Education for Sustainable Development in the Schools Sector from the Panel for Education for Sustainable Development. Available online: http:/ / webarchive.nationalarchives.gov.uk/20080305115859/http:/www.defra.gov.uk/ environment/sustainable/educpanel/1998ar/ann4.htm (accessed on 21 April 2017).

8. de Pauw, J.B.; Gericke, N.; Olsson, D.; Berglund, T. The effectiveness of education for sustainable development. Sustainability 2015, 7, 15693-15717. [CrossRef]

9. De Haan, G. The blk '21'programme in germany: A 'gestaltungskompetenz'-based model for education for sustainable development. Environ. Educ. Res. 2006, 12, 19-32. [CrossRef] 
10. UNESCO. UNESCO and Sustainable Development; UNESCO: London, UK, 2005.

11. Garner, N.; Siol, A.; Eilks, I. The potential of non-formal laboratory environments for innovating the chemistry curriculum and promoting secondary school level students education for sustainability. Sustainability 2015, 7, 1798-1818. [CrossRef]

12. Haubrich, H.; Reinfried, S.; Schleicher, Y. Lucerne declaration on geographical education for sustainable development. Interaction 2008, 36, 39-43.

13. Grindsted, T.S. The matter of geography in education for sustainable development: The case of danish university geography. In Transformative Approaches to Sustainable Development at Universities; Springer: Cham, Switzerland, 2015; pp. 13-24.

14. Morgan, J.; Lambert, D. Geography: Teaching School Subjects 11-19; Psychology Press: Hove, UK, 2005.

15. Naish, M.; Rawling, E.; Hart, C. Geography 16-19: The Contribution of a Curriculum Project to 16-19 Education; Longman: Harlow, UK, 1987.

16. Rawling, E. Changing the Subject: The Impact of National Policy on School Geography 1980-2000; Geographical Association Sheffield: Sheffield, UK, 2001.

17. DfEE/QCA. Geography: The National Curriculum for England, key Stages 1-3; Her Majesty's Stationery Office: London, UK, 1999.

18. Wu, C. Sustainable development concept education in geography teaching. Mod. Educ. Sci. 2010, 1, 2.

19. Zhou, H. Teaching strategy of sustainable development education in geogrpahy curriculum. Mod. Prim. Second. Educ. 2005, 7, 4.

20. Wang, H.; Xu, B. The literature of environment education and sustainable development educaton in secondary school geography. J. Inner Mong. Norm. Univ. (Educ. Sci. Ed.) 2008, 8, 4.

21. Walshe, N. An interdisciplinary approach to environmental and sustainability education: Developing geography students' understandings of sustainable development using poetry. Environ. Educ. Res. 2017, 23, 1130-1149. [CrossRef]

22. Rickinson, M. Researching and understanding environmental learning: Hopes for the next 10 years. Environ. Educ. Res. 2006, 12, 445-457. [CrossRef]

23. Corney, G.; Reid, A. Student teachers' learning about subject matter and pedagogy in education for sustainable development. Environ. Educ. Res. 2007, 13, 33-54. [CrossRef]

24. Chalkley, B.; Blumhof, J.; Ragnarsdóttir, K.V. Geography earth and environmental sciences: A suitable home for esd. Sustain. Educ. Perspect. Pract. Across High. Educ. 2010, 23, 93-108.

25. Taylor, L. Key concepts and medium term planning. Teach. Geogr. 2008, 33, 50-54.

26. Roberts, M. Geography through Enquiry: Approaches to Teaching and Learning in the Secondary School; Geographical Association: Sheffield, UK, 2013.

27. Bertschy, F.; Künzli, C.; Lehmann, M. Teachers' competencies for the implementation of educational offers in the field of education for sustainable development. Sustainability 2013, 5, 5067-5080. [CrossRef]

28. Cebrián, G.; Junyent, M. Competencies in education for sustainable development: Exploring the student teachers' views. Sustainability 2015, 7, 2768-2786. [CrossRef]

29. Cotton, D.R. Teaching controversial environmental issues: Neutrality and balance in the reality of the classroom. Educ. Res. 2006, 48, 223-241. [CrossRef]

30. Oulton, C.; Day, V.; Dillon, J.; Grace, M. Controversial issues-teachers' attitudes and practices in the context of citizenship education. Oxf. Rev. Educ. 2004, 30, 489-507. [CrossRef]

31. Stibbe, A. Words and worlds: New directions for sustainability literacy. High. Educ. Chall. Sustain. Probl. Promises Good Pract. 2007, 5, 283.

32. Lee, J.; Catling, S. Some perceptions of english geography textbook authors on writing textbooks. Int. Res. Geogr. Environ. Educ. 2016, 25, 50-67. [CrossRef]

33. Creswell, J.W.; Guetterman, T.C. Educational Research: Planning, Conducting, and Evaluating Quantitative and Qualitative Research; Pearson: New York, NY, USA, 2007.

34. Reinfried, S.; Rempfler, A. Lucerne declaration on geographical education for sustainable development. Geographiedidaktische Forschungen 2007, 42, 243-250.

35. Williams, A. How to ... write and analyse a questionnaire. J. Orthodo. 2003, 30, 245-252. [CrossRef] [PubMed]

36. Boubonari, T.; Markos, A.; Kevrekidis, T. Greek pre-service teachers' knowledge, attitudes, and environmental behavior toward marine pollution. J. Environ. Educ. 2013, 44, 232-251. [CrossRef] 
37. Khlebosolova, O.; Munich, N.; Guo, F.; Duan, Y. Sustainable Development in the School Geography Education: Current State and Trends Case Studies in Russia, China and the Ukraine; "GolosGubernii" Pubilsher: Moscow / Ryazan, Russia, 2016.

38. MOE\&PRC. Geography Curriculum Standards for Compulsory Education; Beijing Normal University Press: Beijing, China, 2011.

39. Yuan, S.Q.; Liu, J. Geography Textbook for Second Semester in Grade 7, Chapter 8; People's Education Press: Beijing, China, 2012; pp. 70-72.

40. Yuan, S.Q.; Liu, J. Geography Textbook for Second Semester in Grade 7, Chapter 7; People's Education Press: Beijing, China, 2012; pp. 7-25.

41. Yuan, S.Q.; Ding, Y.Q. Geogaraphy Textbook for First Semester in Grade 8; People's Education Press: Beijing, China, 2012; pp. 73-74.

42. Jodoin, J.J.; Singer, J. An Analysis of Environmental Content Found in English-Language Textbooks inJapanese Higher Education Using a Corpus. Int. J. Soc. Sustain. Econ. Soc. Cult. Context 2018, 14, 39-55.

43. International Geographical Union, Commission on Geographical Education. Internaiional Charter on Geographical Education; International Geographical Union, Commission on Geographical Education: Brussels, Belgium, 1992.

44. Prensky, M. Digital Natives, digital immigrants. Horizon 2001, 9, 1-6.

(C) 2018 by the authors. Licensee MDPI, Basel, Switzerland. This article is an open access article distributed under the terms and conditions of the Creative Commons Attribution (CC BY) license (http://creativecommons.org/licenses/by/4.0/). 